Research article

\title{
DEVELOPMENT OF PCR-BASED IDENTIFICATION OF SALMONELLA ENTERICA SEROVARS
}

\author{
KISKÁROLY Ferenc ${ }^{1}$, MORIĆ Ivana ${ }^{2 *}$, ĐOKIĆ Lidija ${ }^{2}$, VASILJEVIĆ Branka ${ }^{2}$, \\ ŠENEROVIĆ Lidija ${ }^{2}$, MIŠIĆ Dušan ${ }^{3}$
}

${ }^{1}$ Specialistic veterinary Institute "Subotica", Subotica, Serbia, ${ }^{2}$ Laboratory for Microbial Molecular Genetics and Ecology, Institute of Molecular Genetics and Genetic Engineering, University of Belgrade, Belgrade, Serbia; ${ }^{3}$ Department of Microbiology, Faculty of Veterinary Medicine, University of Belgrade, Belgrade, Serbia

(Received 22 February, Accepted 08 May 2017)

The aim of the study was to evaluate and adapt the PCR-based protocol that utilizes the developed serotype-specific primers to identify Salmonella enterica species and its serotypes that are most frequently isolated from poultry samples in Vojvodina. Using the slide agglutination test, 64 and 33 out of 107 Salmonella isolates were identified as $S$. Infantis and $S$. Enteritidis, respectively, while ten isolates were identified as eight different Salmonella serovars. Using the same isolates, presence of 993-bp (bcfC gene), 636-bp (steB gene) and 293-bp (sdf locus) amplicons in multiplex PCR unambiguously identified 31 isolates as $S$. Enteritidis. Two isolates identified as Enteritidis in slide agglutination test were not identified as such in PCR-based approach since they both were missing 293bp long PCR product. Thirty-nine isolates produced a 727-bp amplicon in the specific simplex PCR, and thus were identified as $S$. Infantis. The greatest discrepancy in comparison to the results of conventional serotyping has been observed in the case of $S$. Infantis, since 25 more isolates were noted as $S$. Infantis by conventional serotyping. Seven isolates, with unexpected PCR profiles stayed unidentified by molecular typing, although they were serotyped as $S$. Typhimurium (1) and $S$. Infantis (6). S. Gallinarum serovar has to be additionally confirmed, since it shares the same PCR profile with $S$. Livingstone. Clearly, PCR-based identification has to be thoroughly checked, verified and adapted if it is to be applied as the routine identification protocol.

Key words: Salmonella, poultry, multiplex PCR, identification, taxonomy

\section{INTRODUCTION}

In spite of regular and continuous monitoring of the microbial food safety every year millions of people in developed countries still suffer from salmonellosis, one of the most common human infections transmitted via contaminated food [1-5]. According to the European Food Safety Authority (EFSA) from 2007 to 2011, there were 95,548

\footnotetext{
*Corresponding author: e-mail: ivanamoric@imgge.bg.ac.rs
} 
epidemics of salmonellosis in European countries alone, whose source were eggs or chicken meat [6,7]. Therefore, the presence and maintenance of Salmonella in flocks of poultry, as the point of entry of this pathogen into the food chain, is of particular importance [6,7].

Over 1,600 different serotypes belong to Salmonella enterica subspecies enterica, however not all of them are of equal importance as zoonotic agents [4,8-10]. Based on the report from the EFSA, the most frequent serotypes in poultry at the EU level in 2008 were Infantis, followed by Enteritidis, Kentucky, and Typhimurium [6].

Nevertheless, at national level distributions of serovars were quite different. The most frequent serovar in poultry in Hungary was Infantis (over $96 \%$ ), and as such, considerably influencing the overall frequency, became the predominant serovar in poultry in the EU. On the other hand the most common serovar in Lithuania and the Czech Republic in 2008 was S. Agona, while in Sweden the same serovar was found only in one sample. That same year in Ireland the most common serovar was Kentucky, whereas in most other EU countries serovar Enteritidis continued to dominate in poultry. Unlike poultry, according to the latest EFSA report, the most common salmonellosis pathogenic serovar in humans in the EU is Enteritidis, with Typhimurium following close behind it $[4,7]$.

Serotyping is most commonly used method for Salmonella identification, although it is time consuming, laborious, and can be imprecise. During the last three decades different strategies to replace or complement traditional serotyping methods have been proposed, including simplex and multiplex Polymerase Chain Reaction (PCR) protocols [11-16]. PCR methods have a great potential to be an alternative or addition to conventional serotyping due to their simplicity, rapidity, sensitivity, reproducibility, and cost-effectiveness. Although there is a plethora of studies that have used PCR-based methods to identify different Salmonella serotypes, they are usually oriented toward the identification of those serotypes that are prevalent and/or of most importance in a given region or country [11-16].

Therefore, the aim of our study was to evaluate and adapt already developed serotypespecific primers in order to develop a PCR-based protocol for identifying Salmonella enterica species and its serotypes most frequently isolated from poultry in Serbia. To date the data on epizootic prevalence of different Salmonella serotypes in poultry on the territory of Serbia determined by molecular methods are scarce. Molecular serotyping scheme modified to fit our needs combined the work based on whole-genome sequencing and comparative genome analysis performed by Zhu et al. [17] and study of Kardos et al. [18] in order to identify $S$. Enteritidis and $S$. Infantis serotypes, and to cluster other Salmonella serovars in a way that enables their targeted identification either by molecular or conventional identification if necessary. To the best of our knowledge this study is the first attempt to adapt a PCR protocol in order to identify Salmonella serovars in Serbia using molecular approach. 


\section{MATERIAL AND METHODS}

\section{Isolation and identification of Salmonella}

Isolation was performed according to ISO 6579:2002 "Microbiology of food and animal feeding stuffs - Horizontal method for the detection of Salmonella spp." [19]. Poultry fecal samples, carcasses and different organs were used. Samples were taken during 2013-2016 period from different poultry farms in Vojvodina, Serbia, and delivered to the bacteriological laboratory at Veterinary Specialistic Institute Subotica (VSI Subotica) for routine microbiological testing. Buffered peptone water (Becton Dickinson), Rappaport Vasiliadis semisolid agar with novobiocin (Becton Dickinson), XLD agar and SS agar (Becton Dickinson) were used for the cultivation and isolation. Identification of genus Salmonella was performed using API 20 E system (bioMeriux). For the determination of serovars, slide agglutination test was performed using specific diagnostic sera (Bio Rad Laboratories, France; Statens Serum Institut, Denmark).

\section{Isolation of bacterial DNA}

Hundred microliters of bacterial cultures incubated overnight in LB broth at $37^{\circ} \mathrm{C}$ and $180 \mathrm{rpm}$ in a horizontal rotary shaker were used for isolation of DNA with QuickDNA Universal kit (Zymo Research, USA) according to the manufacturer's protocol. Agarose gel (1\%) electrophoresis was used to visualize isolated DNA.

\section{PCR protocols}

Oligonucleotides for the identification of Salmonella enterica serovars used in this study were developed by Zhu et al. [17] and Kardos et al. [18]. We have tested a different number of pairs of primers per a PCR reaction ( 2 to 5 pairs) in various combinations, varied reaction compositions (different concentrations of dNTPs, enzyme, and primers), as well as PCR cycling protocols (ranges of annealing temperatures) using KAPA Taq PCR kit (KAPA Biosystems, USA). Composition for optimized multiplex PCR reactions, performed in $30 \mu \mathrm{l}$, was as follows: $1 \times$ KAPA Taq Buffer B, $0.3 \mathrm{mM}$ of each dNTP, up to $250 \mathrm{ng}$ of genomic DNA as a template, $2.5 \mathrm{U}$ of KAPA Taq polymerase, and three pairs of primers (bcfC-F and bcfC-R for $b c f C$ gene, steB-F and steB-R for steB gene, sdf-F and sdf-R for sdf locus) in final concentrations of $0.4 \mu \mathrm{M}$ each. Two simplex PCR reactions have subsequently been performed to amplify DNK regions that are specific for either $S$. Infantis or $S$. Gallinarum. Each simplex PCR reaction in $30 \mu \mathrm{l}$ volume contained $1 \times$ KAPA Taq Buffer B, $0.2 \mathrm{mM}$ of each dNTP, up to $250 \mathrm{ng}$ of genomic DNA as a template, $1 \mathrm{U}$ of KAPA Taq polymerase, and two primers in final concentration of $0.4 \mu \mathrm{M}$ each (558f and $1275 \mathrm{r}$ for $S$. Infantis; rhs-F and rhs-R for $S$. Gallinarum). Among different annealing temperatures that were tested, the following program was selected for all PCR reactions: after initial denaturation at $95^{\circ} \mathrm{C}$ for 10 minutes, 35 cycles of denaturation at $95^{\circ} \mathrm{C}$ for 30 seconds, annealing at $57^{\circ} \mathrm{C}$ for 30 seconds, and extension at $72^{\circ} \mathrm{C}$ for 70 seconds were performed. Salmonella 
Enteritidis ATCC 13076, S. Infantis ATCC 51741, S. Typhimurium ATCC 14028, and S. Pullorum ATCC 13036 strains were used for PCR optimizations and later as positive controls, while Escherichia coli ATCC 25922 was used as negative control in all amplification reactions. Nucleotide sequences of primers (Invitrogen, USA), size of corresponding PCR products, and names of targeted genes and loci are given in Table 1, while expected multiplex PCR profiles are presented in Table 2. All PCR reactions were carried out in 2720 Thermal Cycler (Applied Biosystem, USA). Agarose gel (1.2 $\%)$ electrophoresis has been used to visualize PCR products.

\section{In silico analysis}

To obtain in silico PCR profiles of $S$. Derby, S. Havana, S. Infantis, S. Mbandaka, $S$. Livingstone, and $S$. Senftenberg serovars, their genome sequences were searched for presence of DNA sequences that used primers specifically amplify. Pairwise alignments was performed using BLAST algorithm [20]. All genome sequences data were obtained from NCBI site (www.ncbi.nlm.nih.gov) and were as follows: [GenBank: LAZB00000000.1] for S. Derby, [GenBank: JWQJ00000000.1] for S. Havana, [GenBank: LN649235.1] for S. Infantis, [GenBank: AMRS01000002] for S. Mbandaka, [GenBank: JZWK00000000.1] for S. Livingstone, and [GenBank: CAGQ00000000.1] for $S$. Senfteberg.

\section{RESULTS}

\section{Conventional identification of Salmonella enterica serovars}

According to conventional method of identification, serotyping, 107 Salmonella isolates were identified as $S$. Infantis (64 isolates), $S$. Enteritidis (33), S. Typhimurium (2), S. Havana (2), and one of each of following serovars - $S$. Agona, $S$. Derby, $S$. Livingstone, $S$. Mbandaka, $S$. Montevideo, and $S$. Senftenberg.

\section{Primers and in silico analysis}

For molecular typing of Salmonella isolates we have chosen to evaluate a set of six pairs of primers that were designed based on comparison of more than 3,000 genome sequences of 108 different Salmonella enterica serovars [17]. In PCR reaction they create unique profiles enabling identification of $S$. Enteritidis (positive for $b c f C$, steB, sdf), $S$. Heidelberg ( $b c f C$, heli, steB), $S$. Kentucky ( $b c f C$, steB, gly), two biotypes of S. Gallinarum serovar - Gallinarum ( $b c f C$, steB, rhs) and Pullorum ( $b c f C$, rhs), and clustering of remaining 104 serotypes in two groups. Those two clusters Zhu et al. [17] labeled as Group 1 and Group 2 according to their PCR profiles which were characterized by amplification of two genes $(b c f C$, ste $B)$ or $b c f C$ gene only, respectively. For the convenience we kept the same classification and labeling. 
Table 1. List of primers with target DNA sequences and PCR product sizes

\begin{tabular}{|c|c|c|c|c|c|}
\hline Primer & 5'-3' sequence & $\begin{array}{c}\text { Target } \\
\text { sequence }\end{array}$ & $\begin{array}{l}\text { Product } \\
\text { size (bp) }\end{array}$ & $\begin{array}{l}\text { Species / } \\
\text { Serovars }\end{array}$ & Ref. ${ }^{*}$ \\
\hline $\begin{array}{l}\text { bcfC-F } \\
\text { bcfC-R }\end{array}$ & $\begin{array}{l}\text { GGGTGGGCGGAAAACTATTTC } \\
\text { CGGCACGGCGGAATAGAGCAC }\end{array}$ & $b c f C$ & 993 & $\begin{array}{c}\text { All } \\
\text { S. enterica }\end{array}$ & \multirow{5}{*}[17]{} \\
\hline $\begin{array}{l}\text { steB-F } \\
\text { steB-R }\end{array}$ & $\begin{array}{l}\text { TGTCGACTGGGACCCGCCCGCCCGC } \\
\text { CСАTCTTGTAGCGCACCAT }\end{array}$ & steB & 636 & $\begin{array}{l}\text { Enteritidis, Gallinarum } \\
\text { biotype Gallinarum, } \\
\text { Group } 1^{\dagger}\end{array}$ & \\
\hline $\begin{array}{l}\text { rhs-F } \\
\text { rhs-R }\end{array}$ & $\begin{array}{l}\text { TCGTTTACGGCATTACACAAGTA } \\
\text { CAAACCCAGAGCCAATCTTATCT }\end{array}$ & rhs & 402 & Gallinarum & \\
\hline $\begin{array}{l}\text { sdf-F } \\
\text { sdf-R }\end{array}$ & $\begin{array}{l}\text { TGTGT"TT"TATCTGATGCAAGAG } \\
\text { CGTTCTTCTGGTACTTCAGATGAC }\end{array}$ & sdf & 293 & Enteritidis & \\
\hline $\begin{array}{l}558 f \\
1275 r\end{array}$ & $\begin{array}{l}\text { AАCAACGACAGCTTATGCCG } \\
\text { CСАCСTGCGCCAACGCT }\end{array}$ & $f j B$ & 727 & Infantis & \\
\hline
\end{tabular}

${ }^{*}$ Given references contain accession numbers of genes and loci used to design primers and exact primers positions at targeted DNA sequence.

\#Salmonella serovars with only bofC positive signal are labeled as Group 2.

${ }^{\dagger}$ For list of serovars that belong to Group 1 and Group 2 see Table 2 footnote.

$b_{c f} C$ - fimbrial usher gene; steB - fimbrial usher gene; rhs - rhs locus; sdf - Salmonella difference fragment; $f j B$ - phase 2 flagellar gene.

However, the genome of one of the most frequently isolated Salmonella serotypes in Serbia, $S$. Infantis [21] was not taken into account for primer design in the study of Zhu et al. [17]. Thus, to determine $S$. Infantis in silico PCR profile we have searched its genome for the presence of the six selected DNA sequences. All pairwise alignments were negative except for $b c f C$ gene indicating that $S$. Infantis serovar did not have unique PCR profile, but belonged to Group 2-type (Table 2). Therefore, to identify $S$. Infantis we have included a pair of primers specific for $S$. Infantis, developed by Kardos et al. [18]. Similarly, other serovars whose genomes were not included in primers' design by Zhu et al. [17], but identified in our study by conventional serotyping ( $S$. Derby, $S$. Havana, $S$. Livingstone, $S$. Mbandaka, and $S$. Senftenberg) were also in silico analyzed. Obtained results revealed that all serovars belonged to Group 1 ( $b c f C$, steB) except for $S$. Livingstone serovar that according to BLAST pairwise alignment shared PCR profile with $S$. Gallinarum biotype Gallinarum $(b c f C$, steB, rhs), an important avian pathogen, causative agent of fowl thyphoid disease.

In all six in silico analyzed genomes heli (predicted helicase) and gly (putative membrane protein) DNA sequences, targeted by primers specific for Heidelberg and Kentucky serotypes, respectively, were absent. As serovars Kentucky and Heidelberg were not found in our study, their specific primers have not been included in a development of PCR-based identification protocol. 
Table 2. Multiplex PCR profiles of Salmonella serovars

\begin{tabular}{llll}
\hline \multirow{2}{*}{$\begin{array}{l}\text { S. enterica serovars } \\
\text { and biotypes* }\end{array}$} & \multicolumn{3}{c}{ Multiplex PCR targets } \\
\cline { 2 - 4 } & bcfC & steB & sdf \\
\hline Enteritidis & + & + & + \\
$\begin{array}{l}\text { Group } 1^{\#} \& \\
\text { Gallinarum biotype Gallinarum }\end{array}$ & + & + & - \\
$\begin{array}{l}\text { Group } 2^{\dagger} \& \\
\text { Gallinarum biotype Pullorum }\end{array}$ & & & \\
\hline
\end{tabular}

${ }^{*}$ For the convenience the same serovars' classification into Group 1 and Group 2 is kept as in Zhu et al. [17]. The only difference is that $S$. Gallinarum biotype Gallinarum and $S$. Gallinarum biotype Pullorum are clustered with Group 1 and Group 2, respectively, according their profiles in context of three genes used in our multiplex PCR.

\#Some of S. enterica subspecies enterica serotypes that have same PCR profile: Agona, Hadar, Havana, Senfteberg, Mbandaka, Derby.

tSome of S. enterica subspecies enterica serotypes that have same PCR profile: Typhimurium, Montevideo, Infantis.

Salmonella serotypes written in italic are analyzed and included in multiplex PCR profiles in this work, while others are selected from original study. For more detailed list on Group 1 and Group 2 see Zhu et al. [17].

According to the results of serotyping, veterinary and clinical importance of Salmonella serovars, and the results of in silico analysis we have chosen five primer pairs that target $b c f C, s t e B$, and $f j B$ genes and, sdf and ths loci in order to adapt PCR protocol(s) for identification of selected Salmonella serotypes.

\section{Multiplex PCR to identify $S$. Enteritidis}

Individual PCR reactions with each primer pair and DNA isolated from reference Salmonella strains were carried out to ensure that each PCR product was of the correct size (data not shown). Agarose gel electrophoresis (Figure 1A) shows that primers within the multiplex PCR were able to clearly identify the appropriate DNA targets. A 993-bp product was amplified from $b c f C$ gene, a 636-bp product from steB gene, while a 293-bp product was amplified from the sdf locus. Presence of all three products unambiguously identified isolate as $S$. Enteritidis (Figure 1A, lane 1). On the other hand, the absence of the 293-bp product indicated that isolate belongs to Group 1 or to Gallinarum biotype Gallinarum (Figure 1A, lane 2; Table 2). If only bcfC gene (993 bp) has been amplified isolate was considered as a member of Group 2 or Gallinarum biotype Pullorum (Figure 1A, lane 3; Table 2).

Out of 107 isolates analyzed in multiplex PCR we have identified 31 as $S$. Enteritidis. Nineteen isolates clustered into Group 1, and 50 isolates into Group 2, while seven isolates exhibited unusual multiplex PCR profile - they were positive for $b c f C$ gene (993 bp) and sdf locus (293 bp), but negative for steB (636 bp). 
Using the PCR-based approach we have identified 31 isolates as $S$. Enteritidis, two less than by conventional serotyping (Table 3). Those two Salmonella isolates were, by multiplex PCR, identified as Group 1 serovars since they both were missing 293-bp long PCR product that amplifies from the sdf locus, which is specific for $S$. Enteritidis $[17,22]$. Seven less frequently isolated serovars identified as $S$. Havana (2), $S$. Agona, $S$. Derby, $S$. Livingstone, $S$. Mbandaka, and $S$. Senftenberg were by multiplex PCR placed into Group 1, as predicted by in silico analysis (Tables 2 and 3).
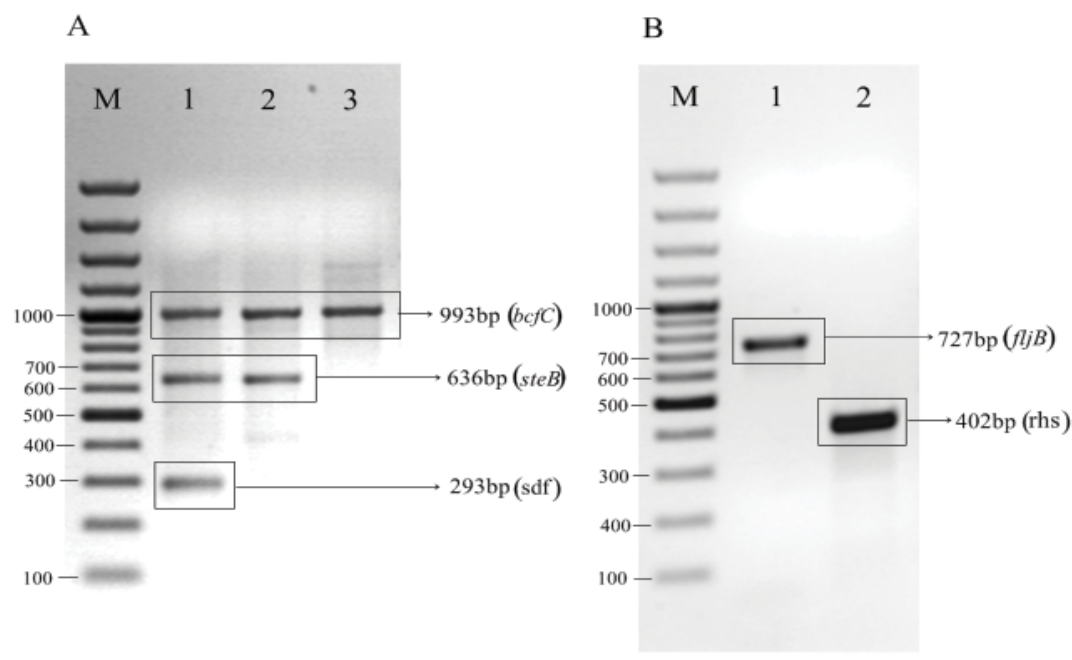

Figure 1. A) Multiplex PCR. Lane M - GeneRuler 100 bp Plus DNA Ladder (Thermo Scientific, USA); Lane 1 - S. enterica serovar Enteritidis; Lane $2-S$. enterica Group 1, according to Table 2; $3-S$. enterica Group 2, according to Table 2. B) Simplex PCRs. Lane M-GeneRuler 100 bp Plus DNA Ladder; Lane 1 - S. enterica serovar Infantis specific band; Lane 2 - S. enterica serovars Gallinarum (both biotypes) and Livingstone specific product. Representative gels from three comparable experiments are given.

\section{PCR-based identification of $S$. Infantis}

In silico analysis showed that $S$. Infantis has a Group 2-type PCR profile, which has been confirmed in individual PCR reactions. Therefore, to differentiate $S$. Infantis isolates from other Salmonella enterica serovars in Group 2, those isolates had to be subjected to simplex PCR using primers specific for Infantis serovar. Nevertheless, in order to evaluate the PCR protocol we have tested all 107 isolates.

Thirty-nine out of 50 isolates from Group 2 produced a 727-bp amplicon (Figure $1 \mathrm{~B}$, lane 1), thus identified as $S$. Infantis, while for 11 isolates this PCR was negative. Obtained results were rather different from the results of conventional serotyping that identified 64 isolates as $S$. Infantis (Table 3). 
Table 3. Similarities and differences in the results between two identification methodologies

\begin{tabular}{ll}
\hline $\begin{array}{l}\text { Multiplex PCR \& } \\
\text { Simplex Infantis PCR }\end{array}$ & Conventional serotyping \\
\hline 31 Enteritidis & 31 Enteritidis \\
\hline 39 Infantis & 39 Infantis \\
19 Group $1 \&$ & 2 Havana, 1 Agona, 1 Derby, 1 Mbandaka, \\
Gallinarum biotype Gallinarum & 1 Seftenberg, 1 Livingstone \\
11 Group 2 & 2 Enteritidis, 10 Infantis \\
\& Gallinarum biotype Pullorum & 1 Typhimurium, 1 Montevideo \\
7 Unidentified & 9 Infantis \\
\hline Total 107 & 1 Typhimurium, 6 Infantis \\
\hline
\end{tabular}

*Numbers of identified serotype or group of serotypes by PCR-based methods for defined category.

\#Results of identification of the same isolates by conventional serotyping. Italic is used to identify differences between PCR and conventional serotyping.

${ }^{\dagger} S$. Livingstone revealed PCR profile identical to Gallinarum biotype Gallinarum - in simplex PCR with primers specific for rhs locus 402-bp long product was obtained.

Twenty-five isolates identified as $S$. Infantis by traditional serotyping when subjected to molecular typing were identified either as isolates of Group 2 since amplification of $f j B$ gene was missing (9) or Group 1 , since ten of them were $b c f C$ and steB positive, but $f j B$ negative. Six out of 25 isolates stayed unidentified by molecular methods. Interestingly, all six isolates had the same unexpected multiplex PCR profile - they were positive for $b c f C$ and sdf, negative for $s t e B$, and when tested for $f j B$ they produced a 727-bp long amplicon.

Two remaining isolates out of 11 from Group 2 that were negative in $f j B$ PCR were true Group 2-type isolates - they were identified as $S$. Typhimurium and $S$. Montevideo (Tables 2 and 3 ).

\section{PCR-based identification of both biotypes of $S$. Gallinarum}

Salmonella enterica serovar Gallinarum is a very important avian pathogen that causes fowl typhoid (biotype Gallinarum) and pullorum disease (biotype Pullorum) [23], and monitoring its presence via PCR protocol is of the great importance. According to our adapted multiplex PCR protocol S. Gallinarum biotype Gallinarum and S. Gallinarum biotype Pullorum would cluster with Group 1 and Group 2, respectively (Table 2). Both S. Gallinarum biotypes can be differentiated from other serovars by performing additional simplex PCR targeting rhs locus [17]. PCR protocol for rhs locus was optimized using S. Pullorum ATCC 13036 strain as a positive control. All isolates were negative for rhs PCR, except for one isolate from Group 1 that was identified by conventional serotyping as $S$. Livingstone. The result was in accordance with in silico 
analysis of the genome revealing that $S$. Livingstone serovar can produce amplicon 402-bp long from its rhs locus.

\section{DISCUSSION}

In this work we have combined published primers to develop a suitable protocol that would enable fast and accurate identification of most frequently isolated Salmonella enterica serovars from samples collected at poultry farms in Vojvodina, Serbia, over the period of three years. We have chosen a set of five primer pairs that target $b c f C, s t e B$, and $f j B$ genes and, sdf and rhs loci. Our attempts to adapt multiplex PCR protocol with all five pairs of primers in the same reaction, which would enable identification of $S$. Enteritidis and $S$. Infantis in one step was unsuccessful. Instead, we have optimized multiplex PCR with three primer pairs, which allowed us to undoubtedly identify $S$. Enteritidis. Other Salmonella enterica serovars were clustered into two groups (including Infantis) based on results of this multiplex PCR. Therefore, to identify $S$. Infantis it would be enough to subject only Group 2-type serovars to simplex PCR that uses $S$. Infantis serovar-specific primers.

The results of $S$. Enteritidis identification by multiplex PCR were in good accordance with conventional serotyping results (94\%) (Table 3). Most likely the difference was due to lack of specificity of slide agglutination since those two isolates were missing sdf amplicons ( $S$. Enteritidis specific) in their PCR profiles.

On the other hand, there was a large discrepancy in the results of $S$. Infantis identification. Out of 64 isolates that were identified as $S$. Infantis by conventional serotyping the same result was obtained for only 39 isolates $(61 \%)$ in simplex PCR. This was unexpected since selected primers were reported to be successfully used in $S$. Infantis identification [18,24-27]. The pair of primers used for identification of $S$. Infantis serovar were designed to amplify practically the entire variable region of the flagellar antigen $f j B$ gene. PCR-based identification protocols that target genes involved in antigen expression enables serovar identification even when their antigens are not properly expressed, and that is a key advantage of PCR in comparison to slide agglutination. Interestingly, we have encountered quite the opposite situation - antigen presence was detected, but not the corresponding gene. It is possible that regions where primers should bind to $f j B$ gene have sufficiently been different from sequences used for their design, thus hindering primers hybridization and gene amplification, but not affecting antigen production. Our result revealed the need for development of novel primers and/or targets for identification of $S$. Infantis. The good search strategy for novel target(s) should rely on genome comparisons of $S$. Infantis genome(s) to genomes of other Salmonella serovars, similarly to the approach that Zhu et al. [17] used. It is worth mentioning that such discrepancy in the results could also be at least partially attributed to drawbacks of traditional methodology used for identification of Salmonella serovars. 
Probably the most intriguing differences between conventional and molecular methods of typing were those related to the identification of seven isolates that exhibited PCR profiles not anticipated to exist as such, at least not among analyzed genomes/serovars. Six of them shared the same pattern - they were positive for $b c f C$ (all Salmonella spp.), sdf locus (specific for $S$. Enteritidis), and $f j B$ (specific for $S$. Infantis) but negative for $s t e B$ which is a part of $S$. Enteritidis identity. Mixed cultures of $S$. Enteritidis and $S$. Infantis as the cause of such an unusual PCR profile have been ruled out due to incomplete $S$. Enteritidis PCR profile. Surprisingly, according to conventional serotyping these six isolates were actually $S$. Infantis. Seventh isolate with uncommon PCR profile was serotyped as Typhimurium, but the PCR profile was not characteristic for PCR Group 2 where this serovar belongs. Instead, its PCR profile was $b c f C$ and sdf positive. Those seven isolated should be further investigated, since sdf locus, located on chromosome has been used as the serovar-specific target in many studies for definite molecular identification of $S$. Enteritidis [22].

Occurring serovars for which genomic data are unavailable at the moment or not included in this study, since they are regarded as less significant, might theoretically exhibit different PCR patterns or share one of defined profiles. Zhu et al. [17] identified rhs locus as DNA target unique to $S$. Gallinarum (both biotypes), but we have found that this invasive agent of chicken salmonellosis shares its PCR profile with $S$. Livingstone, a serovar that is rarely isolated from humans and animals in Europe, but recently has been identified as a major cause of salmonellosis in certain countries [28]. This finding once again emphasizes that interpretation of the obtained results has to be considered carefully and, if necessary identification should be confirmed by employing a different methodology. In the case of S. Gallinarum identification, motility testing and/or conventional serotyping (using just Gallinarum specific antibodies) could be subsequently used to confirm the identity and thus avoid mistakes that can have serious consequences.

\section{CONCLUSIONS}

To the best of our knowledge this is the first attempt to develop PCR protocol in order to molecularly type two most frequently isolated Salmonella serovars in animalrelated samples in Vojvodina. We were partially successful - while multiplex PCR works well and it is in concordance with conventional serotyping, the protocol optimized for $S$. Infantis revealed the need for the search for novel unique targets and for the development of suitable primers. In addition, we have shown that the target considered unique for $S$. Gallinarum (both biotypes) is also present in $S$. Livingstone, serovar emerging as a relevant cause of salmonellosis in certain countries. Obviously, PCR-based identification has to be thoroughly checked, verified and adapted if it is to be applied as the routine identification protocol. 


\section{Acknowledgment}

This work is a part of research realized within the project No.173048 financially supported by the Ministry of Education, Science and Technological Development of the Republic of Serbia. All authors express deepest gratitude to dr Béla Nagy from the Institute for Veterinary Medical Research, Centre for Agricultural Research, Hungarian Academy of Sciences, Budapest, Hungary, for providing us with genomic S. Infantis DNA. IM express her deepest gratitude and appreciation to dr Savvetta for finding the time in her busy schedule to get involved in the results discussion and manuscript writing.

\section{Authors' contributions}

KF organized and performed samples collection, and carried out the experiments. MI performed molecular genetics studies, participated in sequence alignments, conceived of the study, participated in study design and coordination, drafted the manuscript. ĐL participated in sequence alignments and help to draft manuscript. VB, ŠL and MD conceived of the study, participated in study design and helped to draft manuscript. All authors read and approved the final manuscript.

\section{Declaration of conflicting interests}

The author(s) declared no potential conflicts of interest with respect to the research, authorship, and/or publication of this article.

\section{REFERENCES}

1. McDermott PF: Antimicrobial resistance in nontyphoidal Salmonellae. In: Antimicrobial resistance in bacteria of animal origin. Washington DC, USA: ASM Press; 2006, 293-315.

2. CDC (2014), Foodborne Diseases Active Surveillance Network (FoodNet): FoodNet Surveillance Report for 2012 (Final Report). Atlanta, Georgia: U.S. Department of Health and Human Services, CDC.

3. Commission regulation (EC) No 2073/2005 on microbiological criteria for foodstuffs, Official Journal of European Union, L388, Volume 48, 2005, $1-25$.

4. Brands DA: Salmonella and Food-borne illness. In: Deadly diseases and epidemics-Salmonella. Langhorne, PA, USA: Chelsea House Publishers; 2006, 19-27.

5. World Health Organisation, Microbiological Risk Assessment Series: Salmonella and Campylobacter in chicken meat, Meeting Report, 2009.

6. European Food Safety Authority, Scientific Report of EFSA and ECDC: The European Union summary report on trends and sources of zoonoses, zoonotic agents and foodborne outbreaks in 2013, EFSA Journal 2015, 13 (1):3991.

7. European Food Safety Authority, Scientific Report of EFSA: Analysis of the baseline survey on the prevalence of Campylobacter in broiler batches and of Campylobacter and 
Salmonella on broiler carcasses, in the EU, 2008. Part B: Analysis of factors associated with Salmonella contamination of broiler carcasses, EFSA Journal 2011, 9 (2):2017.

8. Andino A, Hanning I: Salmonella enterica: survival, colonization, and virulence differences among serovars. Sci World J 2015, DOI 10.1155/2015/520179.

9. Carlton LG, Prescott JF, Songer G, Thoen CO: Pathogenesis of bacterial infection. Hoboken, NY, USA: Wiley and Blackwell, 4th Edition; 2010.

10. Winn W, Allen S, Janda W, Koneman E, Procop G, Schreckenberger P, Woods G: Koneman's color atlas and textbook of diagnostic microbiology. Philadelphia, PA, USA: Lippincott Williams \& Wilkins, 6th Edition; 2006.

11. McQuiston JR, Parrenas R, Ortiz-Rivera M, Gheesling L, Brenner F, Fields PI: Sequencing and comparative analysis of flagellin genes $f l i C, f j B$, and $f p A$ from Salmonella. J Clin Microbiol 2004, 42:1923-32.

12. Kim S, Frye JG, Hu J, Fedorka-Cray PJ, Gautom R, Boyle DS: Multiplex PCR-based method for identification of common clinical serotypes of Salmonella enterica subsp. enterica. J Clin Microbiol 2006, 44:3608-3615.

13. Tennant SM, Diallo S, Levy H, Livio S, Sow SO, Tapia M, Fields PI, Mikoleit M, Tamboura B, Kotloff KL, Nataro JP, Galen JE, Levine MM: Identification by PCR of non-typhoidal Salmonella enterica serovars associated with invasive infections among febrile patients in Mali. PLoS Negl Trop Dis 2010, 4:e621.

14. Salazar JK, Wang Y, Yu S, Wang H, Zhang W: Polymerase chain reaction-based serotyping of pathogenic bacteria in food. J Microbiol Methods 2015, 110:18-26.

15. Krawiec M, Kuczkowski M, Kruszewicz AG, Wieliczko A: Prevalence and genetic characteristics of Salmonella in free-living birds in Poland. BMC Vet Res 2015, 11:15.

16. Pugliese N, Circella E, Pazzani C, Pupillo A, Camarda A. Validation of a seminested PCR approach for rapid detection of Salmonella enteric subsp. enterica serovar Gallinarum. J Microbiol Methods 2011, 85:22-27.

17. Zhu C, Yue M, Rankin S, Weill F-X, Frey J, Schifferli DM: One-step identification of five prominent chicken Salmonella serovars and biotypes. J Clin Microbiol 2015, 53: 3881-3883.

18. Kardos G, Farkas T, Antal M, Nogrady N, Kiss I: Novel PCR assay for identification of Salmonella enterica serovars Infantis. Lett Appl Microbiol 2007, 45:421-425.

19. ISO 6579:2002 (E). Microbiology of food and animal feeding stuffs - Horizontal method for the detection of Salmonella spp. (2002) $4^{\text {th }}$ Ed., International Standard, Geneva, Switzerland.

20. Altschul S, Gish W, Miller W, Myers E, Lipman D: Basic local alignment search tool. J Mol Biol 1990, 215:403-410.

21. Velhner M, Kozoderović G, Grego E, Galić N, Stojanov I, Jelesić Z, Kehrenberg C: Clonal spread of Salmonella enterica serovar Infantis in Serbia: Acquisition of mutations in the topoisomerase genes $g y r A$ and $\operatorname{par} C$ leads to increased resistance to fluoroquinolones. Zoonoses Public Hlth 2014, 61:364-70.

22. Agron PG, Walker RL, Kinde H, Sawyer SJ, Hayes DC, Wollard J, Andersen GL: Identification by subtractive hybridization of sequences specific for Salmonella enteric serovars Enteritidis. Appl Environ Microbiol 2001, 67:4984-4991.

23. Shivaprasad HL, Methner U, Barrow PA: Salmonella infections in the domestic fowl. In: Salmonella in domestic animals. Wallingford, United Kingdom: CABI; 2013, 162-192. 
24. Nogrady N, Kardos G, Bistyak A, Turcsanyi I, Meszaros J, GalantaiZs, Juhasz A, Samu P, Kaszanyitzky JE, Paszti J, Kiss I: Prevalence and characterization of Salmonella Infantis isolates originating from different points of the broiler chicken-human food in Hungary. Int J Food Microbiol 2008, 127:162-167.

25. Chironna M, Tafuri S, Gallone MS, Sallustio A, Martinelli D, Prato R, Germinario C: Outbreak of Salmonella Infantis gastroenteritis among people who had eaten at a hash house in southern Italy. Public Health 2014, 128:438-443.

26. Shimizu R, Osawa K, Shigemura K, Yoshida H, Fujiwara M, Iijima Y, Fujisawa M, Shirakawa T: Development of multiplex PCR for rapid identification of four Salmonella serovars most commonly isolated in Japan. Southeast Asian J Trop Med Public Health 2014, 45:654-661.

27. Ghoddusi A, Nayeri Fasaei B, Karimi V, Ashrafi Tamai I, Moulana Z, Zahraei Salehi T: Molecular identification of Salmonella Infantis isolated from backyard chickens and detection of their resistance genes by PCR. Iran J Vet Res 2015, 16:293-297.

28. Guedda I, Taminiau B, Ferjani A, Boukadida J, Bertrand S, Daube G: Antimicrobial and molecular analysis of Salmonella serovar Livingstone strains isolated from humans in Tunisia and Belgium. J Infect Dev Ctries 2014, 8:973-980.

\section{IDENTIFIKACIJA SEROVARIJETETA VRSTE SALMONELLA ENTERICA PCR METODOM}

KISKÁROLY Ferenc, MORIĆ Ivana, ĐOKIĆ Lidija, VASILJEVIĆ Branka, ŠENEROVIĆ Lidija, MIŠIĆ Dušan

Cilj rada je bila evaluacija i primena već opisanih PCR protokola u identifikaciji serotipova vrste Salmonella enterica podvrste enterica u ispitivanjima serotipova Salmonella koji su u najvećem procentu prisutni na živinarskim farmama sa područja Vojvodine. Primenom testa brze aglutinacije na pločici, od 107 ispitivanih izolata Salmonella, 64 izolata su identifikovana kao serovarijet Enteritidis, 33 kao Infantis, dok je deset izolata pripadalo drugim serovarijetetima (8 serovarijeteta). Primenom multipleks PCR metode u identifikaciji istih izolata, kod 31 izolata utvrđeno je prisustvo amplikona dugih 993 bp (bcfC gen), 636 bp (steB gen), odnosno 293 bp (sdflokus), na osnovu čega su identifikovani kao $S$. Enteritidis. Dva izolata, identifikovana u testu aglutinacije na pločici kao $S$. Enteritidis, prema rezultatima multipleks PCR nisu pripadala tom serovarijetetu, jer je izostalo umnožavanje fragmenta dugog 293 bp. U simpleks PCR reakciji kod 39 izolata umnožen je amplikon dužine 727 bp, i ovi izolati su identifikovani kao S. Infantis. Najveća neslaganja u rezultatima serološke tipizacije i PCR identifikacije dobijeni su kod serovarijeteta Infantis, gde je čak 25 izolata više identifikovano kao Infantis $\mathrm{u}$ testu aglutinacije. Sedam izolata, koji su u testu aglutinacije bili identifikovani kao $S$. Typhimurium (1), odnosno S. Infantis (6) nije bilo moguće identifikovani molekularnim pristupom, pošto su imali neočekivane PCR profile. U identifikaciji serovarijeteta $S$. Gallinarum neophodno je koristiti dodatne testove, jer je pokazano da serovarijetet Liv- 
ingston ima isti PCR profil. Očigledno je da pre nego što se identifikacija zasnovana na PCR metodi uvede kao rutinska, potrebno je detaljno proveriti, potvrditi i prilagoditi postojeće protokole sopstvenim potrebama. 